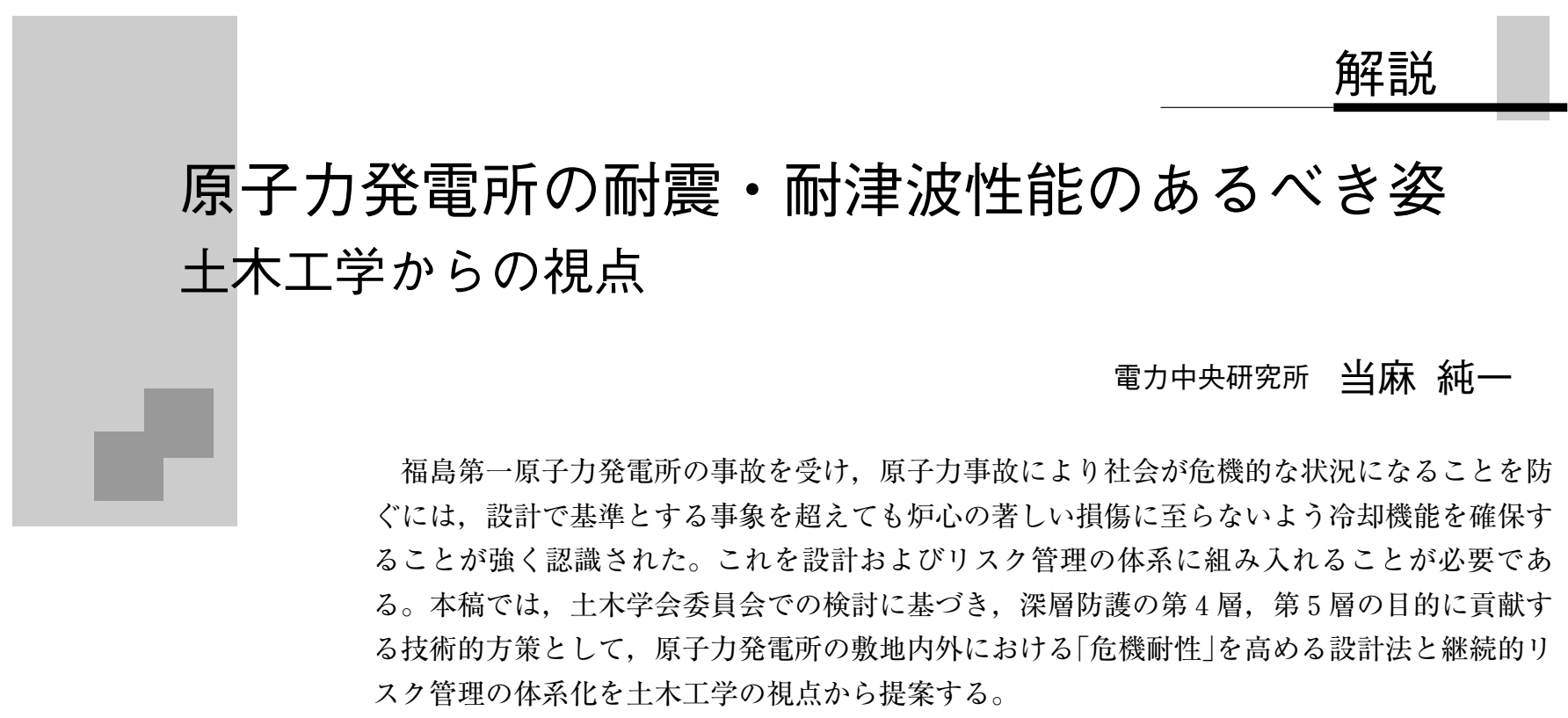

\section{I ．はじめに一問題の所在一}

福島第一原子力発電所の事故を踏まえると，放射性物 質の大量放出により社会が危機的な状況になることを防 ぐには，設計で基準とする事象を超えても炬心の著しい 損傷に至らないよう冷却機能を確保することが設計掞よ びリスク管理上の要求として明らかになった。土木学会 では震災後に「原子力安全土木技術特定テーマ委員会」を 組織し，この論点の議論を深め，このたび提言を取りま とめた。この提言は, 原子力発電において土木工学が係 わる安全規制行政，電気事業，国，自治体，建設業，学 協会などで活動する技術者を主な対象としている。

原子力安全の確保は深層防護の考え方が基本とされて いる。国際原子力機関 (IAEA)によれば防護層は, 異常 運転打よび故障の防止 (第 1 層), 異常運転の制御及び故 障の検出(第 2 層), 設計基準内への事故の制御 (第 3 層), 事故の進展防止及びシビアアクシデントの影響緩 和 (第 4 層)，放射性物質の放出による放射線影響の緩和 (第 5 層)により構築される ${ }^{1} 。$

本稿では, この考え方に照らし, 深層防護の第 3 層ま での土木工学的課題に関しては基準とする地震動や津波 に対する設計・施工技術で対応するものと捉え，主には 深層防護の第 4 層に貢献すべき新たな土木工学的課題に 注目した。さらには，第 5 層の目的を達成すべき課題の 一部を検討した。

まず，議論の前提として今般の事故を土木工学から省 みると, 以下の問題が所在していることを委員の共通認 識とした。

Performance-Based Design and Risk Management of Nuclear Power Plant for Earthquake and Tsunami : Junichi TOHMA.

(2013年 5 月17日 受理)
1. 自然現象は設計で基準とする值を上回ること があるという認識の欠如

設計地震動，設計津波を上回る事象に対して，どのよ うな対策が現実的に適切であるかという認識が社会で共 有されていなかった。

原子力発電所の設計では「極めてまれな地震，津波」を 想定する。これらを科学合理的に設定する努力はこれま でもなされてきた。土木分野においても，断層の活動性 研究や設計津波の研究に取り組んできた2)。しかし，新 潟県中越沖地震では設計地震動を大きく上回る地震動が 発生し，その後，東日本大震災では設計津波を大きく上 回る津波が発生した。その結果，設計で基準とする值の 決め方への疑念が社会に広がるとともに，設計で基準と する值を上回る事態への対応が大きな問題となった。

「極めてまれな地震, 津波」に対応して設計地震動や設 計津波を定めるということは，それがゆえに，その後の 新知見への対応が容易ではないという問題を内包してき た。場合によっては, それ以前の意思決定根拠の否定に つながり，原子力安全の説明性に一貫性を欠くからであ る。このことはまた，設計で基準とする值を上回る可能 性への継続的なリスク管理を妨げてきた原因にもなっ た。

「極めてまれな地震，津波」を科学合理的に設定するこ との努力と同程度以上に，設計で基準とする值を上回る 事態に備えての事前・事後の対策を広く検討することが 原子力に関わる各分野で必要であったのではないか。

\section{2. 発電所周辺地域の視野からの安全技術の欠如}

設計地震動, 設計津波を上回る事象に対して, 発電所 敷地内だけでなく, 敷地外との関わりを含めての対策の 整備が不足していた。

東日本大震災で送電線やオフサイトセンターが機能岥 
失したことに象徴されたように, 発電所の安全で問題と なるような地震や津波が発生すれば，敷地外においても 相当の被害を生じている可能性があることを筆者は震災 以前から次のように指摘していた。「地震にせよ，津波 にせよ，自然現象は特定の施設を選択的に襲う訳ではな い。したがって，これからは，「ある原子力発電所で設 定している設計地震動や設計津波がもし発生したら, 敷 地内外全体はどうなるのか，地域はどうなるのか。近隣 諸国はどうなるのか。」というイメージ力を持ち，それ を国内外の多くの関係者と共有することが大事であるよ うに思う。これは，原子力に携わる者だけでなく，原子 力以外の社会インフラの設計・施工に携わる側に対して も襄返しに言えることである。それぞれの分野の技術基 準によって設計された施設が，大自然災害時にどのよう な機能が果たせるか。緊急時の道路, 港湾の機能はどう か。この社会的なやりとりこそが，常識的で適正な安全 レベルを保つ手段となる。」)

東日本大震災で, 敷地外に扔ける道路交通や供給イン フラの確保や, 必要資材の備蓄も不可欠であり, 関連行 政や他事業者との連携が重要であることが強く認識され た。

東日本大震災以前は, 敷地外での穾質的な防護措置が 必要となるような事故の事態を想定してこなかった。そ の裏返しとして，事故を想定した議論がタブー視され， 敷地内と敷地外とのかかわりが真剣に議論されることが なかった。設計で基準とする值以下の事象においての発 電所(あるいはその所有会社)で完結した事態収束が前提 となっていた。

原子力安全の目標を達成するためには，こうした「発 電所周辺地域の視野からの安全技術」の整備も十分にな されていることが必要であったのではないか。

\section{II . 新たな耐震・耐津波設計とリスク 管理への提案}

1. 新たな耐震・耐津波設計とリスク管理の枠組み

従来考慮されていた，基準地震動・津波に対する性能 である「安全性」に加え, 基準地震動・津波を超えるなど により「安全性」が損なわれた場合の「危機耐性」を新たに 性能として考虑することを提案する。

原子力発電所に限らず，設計基準のレベルを高くすれ ばするほど安全性は高まるが，それでも設計基準を超え る事象に対しての危険は残っている(第 1 図)。ここでの 「安全性」の定義は一般に「重大な損傷が発生しない」であ り, 原子力発電所施設では「緊急手段を必要とせずに放 射性物質の大量放出という危機的な状況に至る可能性を 十分に小さくする性能」と捉える。この「安全性」が損な われたとしても直ちに危機的な状況に陥ることは避けな くてはならない。安全性能を超えることは構造物に重大 な損傷が発生することを意味するが，そのような場合で
「安全」と「危険」は連続的, 絶対安全はない

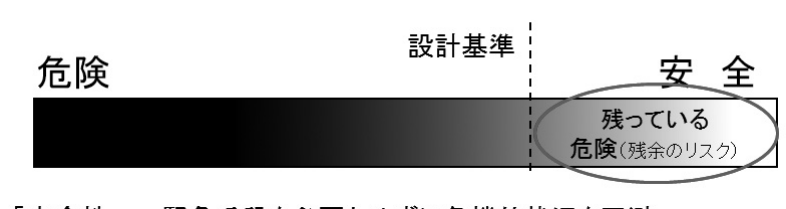

「安全性」：緊急手段を必要とせずに危機的状況を回避

（構造物に重大な損傷を生じさせない）

「安全性」に関する設計 $\Leftrightarrow$ 基準地震動, 基準津波

それでも残っている「危険」への対処 $\rightarrow$ 危機耐性」

第 1 図 安全性のレベルと設計基準(吉田, 土木学会主催シ ンポジウム「東日本大震災から 2 年」2013.3.13より)

も緊急手段の実行を可能とし，原子力発電所のシステム 全体として危機的な状況に至る可能性を十分に小さくす る性能を定義すべきである。この性能の名称として,「危 機耐性 (anti-catastrophe)」を用いる。

基準地震動・津波以下に対しては「安全性」，それ以上 に対しては「危機耐性」が保たれなくてはならない。な お，これらの性能を確保する上で構造物の劣化が「危機 耐性」などの性能に大きな影響を与えないように適切な 維持管理を行わなくてはならない。

\section{2. 新たな性能 $\lceil$ 危機而性」}

「危機耐性」を考える場合, 原子力発電所内の個々の施 設や構造物の損傷による波及効果を十分に理解し, 原子 力発電所を一つのシステムとしてモデル化する必要があ る。システムのモデル化は, 原子力発電所内で生じる個々 の施設や構造物の地震や津波による損傷・被害の影響範 囲を明らかにすることに直結している。モデル化された システムに基づき被災シナリオが構築されるため，シス テムさらにはその中のサブシステム，さらにはその中の 個々の要素の相互の関係を明確にしなければならない。 原子力, 土木, 建築, 機械, 電気などの技術分野の坦根 を越えた工学連携により各分野が係わるサブシステムで 構成されるシステム全体について総合的に検討すること が重要である。

例えば, 屋外重要土木構造物や周辺斜面が被害を受け たとしても，それが原子力発電所の危機的な状況をもた らすような被害であってはならない。新潟県中越沖地震 (柏崎刈羽原子力発電所), さらには東日本大震災 (福島 第一，第二原子力発電所ほか)でも，これら自体が地震 動で壊れることなく耐震性の高さを実証した形になった が, 耐震重要度のより低い構造物との取り付け部に被害 が集中するなどして，システム全体の修復・復旧を困難 にした事例もみられた。また，水位計の止水部が津波の 押し波で壊れたために, 取水設備から原子炉建屋附属棟 への海水流入により冷却系の重要機器が浸水し, 冷却機

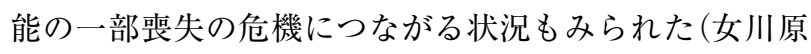


子力発電所)。

これまで, 壊れ方, 壞れた後の影響の検討はあまり行っ てこなかったが，もし壊れるとしても危機的な状況を避 けるような壊れ方を検討することが今後重要である。そ のためには部材レベルの照査だけではなく, 構造物全体 として，あるいはシステム全体として危機的な状況を避 けるための方策を考える必要がある。取水施設であれば 基準地震動・津波を超えたとしても直ちに冷却水確保の ための通水性が損なわれるような破壊形態は避けなくて はならない，通水性が損なわれたとしても緊急手段によ る対処を阻害するような被害形態は避けなくてはならな い。このようにシステム全体として粘り強いものとする ことが重要である。「危機耐性」の確保は, 所定の設計外 力に対して照査を行う従来の設計の方法とは異なり, あ る施設の損傷がどのような波及効果を及ぼすかを考え， 過酷事故に至るような状況を回避するための対策を講じ ることによって達成される。その具体的方法は今後議論 を重ねる必要があるが，ストレステストと確率論的リス ク評価とを相互補完的に合わせて用いることはその一つ の方法と解釈できる。

また，緊急手段により「危機耐性」を保つことも大変重 要であり,その際, モニタリングの果たす役割は大きい。 津波の到達前での建屋等の開口部の閉鎖㧍よび作業員の 避難等の緊急手段は，原子力発電施設における津波の影 響を低減し，危機的な状況から遠ざける効果がある。こ れらの方策を適切に実施するためには, 津波の到達時刻 や水位変動量の予測が必要である。沖合に扔ける水位モ ニタリングはその精度を高める有効な手段の一つであ り, GPS 波浪計データや海洋レーダの活用が期待され る。また, 津波到達後に, 危機的な状況を避けるために, 浸水した機器の代替機器の設置などの緊急手段を行う可 能性がある。しかし，巨大津波が発生すると，その水位 変動は数時間から最大で 1 日程度継続する場合があり, 作業の実施の可否判断には津波に関する情報が必要であ る。この情報を得る主要な手段の一つが, 原子力発電所 敷地内と周辺のモニタリングであり, 例えば水位等の観 測や映像によるモニタリングにより現場の状況を把握す ることができる。また，モニタリング結果を記録するこ とにより，津波が発電所に与えた影響を直後に確認する ことは，緊急手段の選択に有効である。こうした情報を 有効に活用した適切な緊急手段によって「危機耐性」を高 めることが期待できる。

なお，新たな性能である「危機耐性」を導入したとして も，原子力発電所が地震や津波により危機的な状況に至 る可能性を完全にはゼ口にできないことを十分に認識 し, 継続的にリスク管理の改善を図っていかなくてはな らない。

\section{III. 原子力安全確保に向けた発電所 敷地外の周辺地域との関わり}

\section{1. 発電所周辺地域の視野からの修復・復旧}

原子力安全土木技術の根幹は, 地震・津波ハザードの 評価技術や耐震設計及び耐津波設計に関わる技術である が，一方で，原子力発電所の物理的・機能的な被害の可 能性を想定すれば，危機的な状況を避けるための修復・ 復旧に係わる活動やそれらを支える周辺地域からの応 援・支援は不可欠となる。そのためには，設計とする地 震動や津波を超える自然現象を想定した場合に，原子力 発電所の立地する地域全体の社会インフラがどのような 地震・津波被害を受ける可能性があるのかが，危機回避 の与条件として必要になる。たとえば，土木工学の視点 からは, 建物の倒壊, 地域の浸水, 橋の崩壊やトンネル の崩落, 液状化による交通阻害などがある。これらのイ ンフラが被災原子力発電所の復旧にどのような影響を及 ぼすか，どの程度の事前・事後対策を用意すればよいか を，関係する機関が相互調整する必要がある。

電気事業者, 国の関係機関拈よび立地自治体を含め て, 我が国の社会全体で原子力発電所の物理的・機能的 な被害の可能性をこれまで暗黙裡に前提としてこなかっ た。それゆえ, 被害収束に向けた原子力発電所の修復・ 復旧という考え方が原子力安全土木技術の枠組みの中で 十二分に制度化されていなかった点が大きな問題の一つ であった。その結果，危機的な状況での，時間的・空間 的に極めて強い制約下において原子力発電所を修復・復 旧させるためのアクションプランや具体的な方策が欠落 していたと考えられる。

危機耐性の考え方を国際原子力機関 (IAEA)による哚 層防護の考え方に対応づけると，第 4 層で必須となるア クシデントマネジメント，第 5 層で必須となる敷地外緊 急対応に関与する性能であり，このような性能を確保す るためには，周辺地域との関わりの中での修復・復旧と いう考え方が前提として求められることになる。

\section{2. 修復・復旧を前提とした社会制度の枠組み}

原子力安全土木技術に係わる修復・復旧の考え方を, 社会制度の枠組みの中でどのように位置づけ, 共有・運 用・管理・維持していくかが, 極めて大きな課題であ る。その課題解決には, 様々な分野との協働・連携作業 が不可欠である。

原子力発電所周辺の地域社会との関わりの中で, 修 復・復旧を前提とする原子力防災の基本的な枠組みを, 災害対策基本法や原子力災害対策措置法といった上位法 令の中で明文化し，それによって，各省庁の原子力災害 対策マニュアル, 関連自治体の総合計画・地域防災計画 および電気事業者の防災業務計画の策定過程の组上に載 せ,アクションプラン等の具体的な施策立案の際に修 
復・復旧の考え方を反映させる必要がある。

その際，学会や行政など中立な第三者機関の役割とし ては,アクションプラン策定のための指針や手引書の策 定・公表・改定などの責任的立場が求められよう。さら に主体を広げると，政府機関には，住民を含めた，原子 力安全に係わる個別分散的な主体間のリスクコミュニ ケーションを前進かつ効率化するために, 原子力安全に 係わるリスク情報を一元的に共有するプラットホームを 再構築した上で公開し, 実質的でかつ効率的な運用・管 理・維持に向けた迅速な行動が強く求められる。

\section{3. 原子力発電所の危機耐性を確保するための 敷地外システムの耐性の向上}

「危機耐性」という性能を原子力発電所に求めるために は, 原子力発電所の修復・復旧を周辺地域との関わりの 中で具体化し，効率的に実現することが不可欠となる。 このためには, 原子力発電所の敷地外システムの耐性の 向上方策を講じておく必要がある。対象とする原子力発 電所の物理的・機能的な被害による影響波及をイベント ツリー解析の方法論を援用するなどして事前検討し, 帰 結となる事態の事故シーケンスを遡って敷地外システム の耐性を向上させる必要がある。

原子力発電所の敷地外システムとして, 具体的には, 国・自治体等が関わるオフサイトセンター等の危機管理 および応急復旧の基点となる公的施設や, 電気事業者等 が関わる復旧人員・復旧資機材の供給拠点となる後方支 援拠点群，また，それらから原子力発電所までの交通イ ンフラ・アクセスルート, 及び, 電力供給, 情報通信, 水供給・水処理等のライフラインシステムが挙げられる。

先に述べた深層防護の第 5 層 (放射性物質の放出によ る放射線影響の緩和) が発動される事態において，これ が確実に達成されるためには, それぞれの事故シーケン スを想定した上で, 地震動, 液状化等による地盤の変状, 斜面崩壊，津波，さらには空間放射線による被曝などに 対する原子力発電所の敷地外システムのリスク管理が必 要不可欠である。たとえば，避難や応援に支障となる被 害が発電所周辺の道路, 河川, 港湾などに生じていない かは重要であり, その事前・事後対策は土木工学が大き く貢献できる技術分野でもある。

また，危機的な状況に応じて空間的に対象領域を拡大 して修復・復旧の効率化に係る方策を検討する必要があ る。したがって, 原子力災害対策の重点区域だけでなく, さらに広域からの応援・支援を念頭においた上記のリス ク管理と具体的な方策の検討が必要である。

なお，このようなリスク管理と具体的な方策の検討に あたっては, 電気事業者と他の事業者が密接に関わる必 要があるため, 実効性を高めるための制度設計が喫緊の 課題となろう。このような制度設計に際しては, 上記の 敷地外システムに関わる事業主体が具体的な方策を実施
する際のコストの負担について検討することも併せて必 要である。

\section{IN . 土木技術者の役割}

一般の社会基盤施設では，地震，津波など自然外部事 象への理解と対策において土木技術は大きく関与してき ている。そうした総合的な防災技術力があるにもかかわ らず，原子力安全においては土木分野からの情報発信や 他の技術分野との連携が十分とはいえなかった。東日本 大震災での原子力事故を機に，原子力，土木，建築，機 械, 電気の分野間での垣根を越えた協力関係が良好に構 築されつつある。特に, 次に示す課題について, 分野間 の協力関係を密にして対応していく必要がある。

\section{1. 失敗・成功事例等の共有と活用}

失敗事例から再発防止の教訓を得るとともに，東日本 大震災で過酷事故に至らせなかった他のサイトでの経験 を技術として体系化して今後に引き継いでいくべきであ る。

東日本大震災では過酷事故に至った失敗事例から, 社 会は多くの教訓を得た。これらを今後の安全に活かすこ とは当然として，過酷事故に至らせなかった成功体験も あり，これらを事例として共有して今後に活かすべきで ある。たとえば，東北電力女川原子力発電所では，基準 地震動 Ss と同程度の地震動を経験したが, 耐震安全上 重要な土木構造物, 基礎地盤, 周辺斜面に顕著な被害は なかった。最高水位 $13 \mathrm{~m}$ の巨大津波であったが主要設 備を設置している敷地には津波は到達しなかった。過去 から現在に至るまでの土木技術が有効に寄与しているも のと考えられる。また，震災後に各原子力発電所で個別 に実施されている緊急安全対策についても，その設計 法, 施工法, 耐震性評価法, 耐津波性評価法などを技術 として体系化し将来に引き継いでいくことが重要であ る。

\section{2. 継続的なリスク管理への関与}

原子力発電所は，常に最新の地震・津波工学に関わる 知見を取り入れ，「危機耐性」などの新たに定義される性 能も考慮し，継続的にリスク管理を行うことが求められ る。さらには, 今後も原子力発電所近傍における地震や 津波の情報が新たに提供されることが予想されるため, これらに対する原子力発電所のリスクを管理し, 受容で きるように補強を含めた対策を施す必要がある。

継続的なリスク管理を行っていく上で，モニタリング 技術の積極的な活用も重要である。中小の地震も含めた 地震動, 各種構造物の応答, 津波などの観測情報から設 計やリスク評価に用いたモデルの妥当性を確認し，必要 に応じて更新する耐震・耐津波設計, リスク管理の仕組 みを構築していくことが好ましい。 
さらには，構造物の耐震性・耐津波性に関するリスク とその対策に関わる情報を第三者の立場から公開するシ ステムを構築し，市民感覚を反映した意思決定の仕組み を持つべきである。

\section{$\mathrm{V}$. 提言のまとめと今後の取り組み}

設計で基準とする地震動や津波を超える事象が発生し た場合でも，深層防護の目的を達成することを可能と し，原子力発電所のシステム全体として危機的な状況に 至る可能性を十分に小さくする性能を「危機耐性」と定義 した。これを発電所敷地内外の関連施設の設計やリスク 管理の枠組みに取り入れることが必要である。

震災を受け，土木分野では，津波が浸水した場合の構 造物への波力, 津波浮遊物の構造物への衝突力, 海洋レー ダによる津波の沖合検知, 周辺斜面の地震時変形予測と 崩壊対策, 地表断層変位が構造物安定性に及ぼす影響な どの調查研究に力を入れている。これらは危機耐性の向 上に寄与するものと考えている。

\section{VI.あとがき}

本稿は，東日本大震災を受け土木学会が設置した「原 子力安全土木技術特定テーマ委員会」による検討に基づ いたものであり, 委員会が作成中の提言案 ${ }^{4}$ の基本部を
土木学会主催シンポジウム「東日本大震災 2 年」(平成 25 年 3 月 13 日) で討議した内容に基づき紹介した。提言は 関係資料とともに2013年 7 月を目途に完成し公表する予 定である。

\section{一参 考 資 料一}

1）山口彰, 原子炉施設の確率論的リスク評価の動向と今後 への期待, 日本原子力学会誌，54[3]，184(2012).

2）たとえば，(社) 土木学会 原子力土木委員会津波評価部 会, 原子力発電所の津波評価技術, 2002.2.

3）当麻純一, 耐震安全性の相場観の形成, 土木技術, 土木 技術社，2010.8.

4）原子力発電所の耐震・耐津波性能のあるべき姿に関する 提言 (土木工学からの視点) (案), 土木学会 東日本大震 災フォローアップ委員会 原子力安全土木技術特定テー マ委員会, 2013.2.

著者紹介

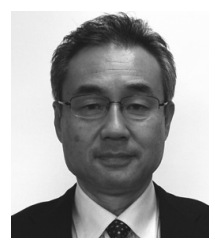
当麻純一(とうま・じゅんいち) 電力中央研究所 (関心分野/専門分野) 土木工学, 地震工学, 原子力土木

\section{日本原子力学会誌 ATOMOE 広告のご案内}

一般社団法人 日本原子力学会

「日本原子力学会誌」は, 特集・解説・講演等, 広く原子力に関わる記事を掲載し, 我が国の原子力研究, 産業の発展に資す るべく, 努力しております。学会誌は毎月約 8,000 部が発行されており, 電力, メーカー, 大学, 研究機関を中心とする会員 および賛助会員の原子力関係者はもとょり，広く原子力関係機関，市町村，マスコミ等にわたっております。本誌への広告揭 載は，発展の一助になるものと信じておりますので，ぜひ，広告の掲載をお願い申し上げます。

口賛助会員料金(消費税別)

\begin{tabular}{|ll|l|}
\hline 表 2 & 150,000 円 & 前付 110,000円 \\
\hline 表 3 & 140,000 円 & 後付 100,000円 \\
\hline 表 4 & 190,000 円 & 差し込み 230,000円 \\
\hline
\end{tabular}

※差し込みは本誌に同封となります。

\section{口一般料金 (消費税別)}

\begin{tabular}{|ll|l|}
\hline 表 2 & 160,000 円 & 前付 120,000円 \\
\hline 表 3 & 150,000 円 & 後付 110,000円 \\
\hline 表 4 & 200,000 円 & 差し込み 240,000円 \\
\hline
\end{tabular}

上記の金額は，1ページあたりのモノクロの料金です。カラーの場合，1ページあたり 120,000 円追加となります。 また，版下・フィルム製作費は別途申し受けます。

過去 1 年以上毎月出稿された機関につきましては 10,000 円引きとなります。

口連絡先 105-0004東京都港区新橋2-3-7新橋第二中ビル $3 \mathrm{~F}$ ，一般社団法人日本原子力学会 学会誌編集担当 富田，野口 TEL 03-3508-1262, FAX 03-3581-6128, E-Mail : hensyu@aesj.or.jp

口詳 細 http://www.aesj.or.jp/atomos/atomoskoukoku.html 